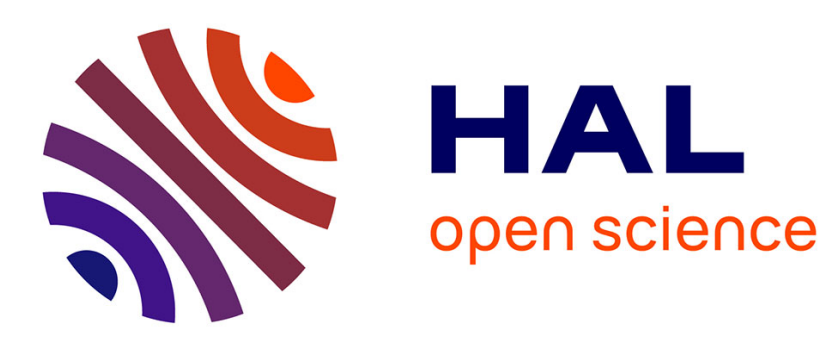

\title{
Training in medical hypnosis and prolonged use of benzodiazepines: The French National Health Insurance Data
}

Léa Légereau

\section{- To cite this version:}

Léa Légereau. Training in medical hypnosis and prolonged use of benzodiazepines: The French National Health Insurance Data. Human health and pathology. 2020. dumas-02962714

\section{HAL Id: dumas-02962714 https://dumas.ccsd.cnrs.fr/dumas-02962714}

Submitted on 9 Oct 2020

HAL is a multi-disciplinary open access archive for the deposit and dissemination of scientific research documents, whether they are published or not. The documents may come from teaching and research institutions in France or abroad, or from public or private research centers.
L'archive ouverte pluridisciplinaire HAL, est destinée au dépôt et à la diffusion de documents scientifiques de niveau recherche, publiés ou non, émanant des établissements d'enseignement et de recherche français ou étrangers, des laboratoires publics ou privés. 
UNIVERSITÉ DE NICE SOPHIA ANTIPOLIS

FACULTÉ DE MÉDECINE

THÈSE D'EXERCICE POUR LE DIPLÔME D'ÉTAT DE DOCTEUR EN MÉDECINE

\section{Training in medical hypnosis and prolonged use of benzodiazepines: The French National Health Insurance Data.}

Présentée et soutenue publiquement le lundi 24 aout 2020 à $17 \mathrm{~h}$

À la faculté de médecine de Nice

Par

Madame LÉGEREAU Léa

Née le 23 mars 1992 à NIORT (79)

JURY :

Membres du jury:

- Professeur Marc RAUCOULES-AIMÉ

PRESIDENT DU JURY

- Professeur Patrick BAQUÉ

ASSESSEUR

- Professeur Brigitte MONNIER

ASSESSEUR

- Docteur Johann TÉTART

ASSESSEUR

Directeurs de Thèse : 


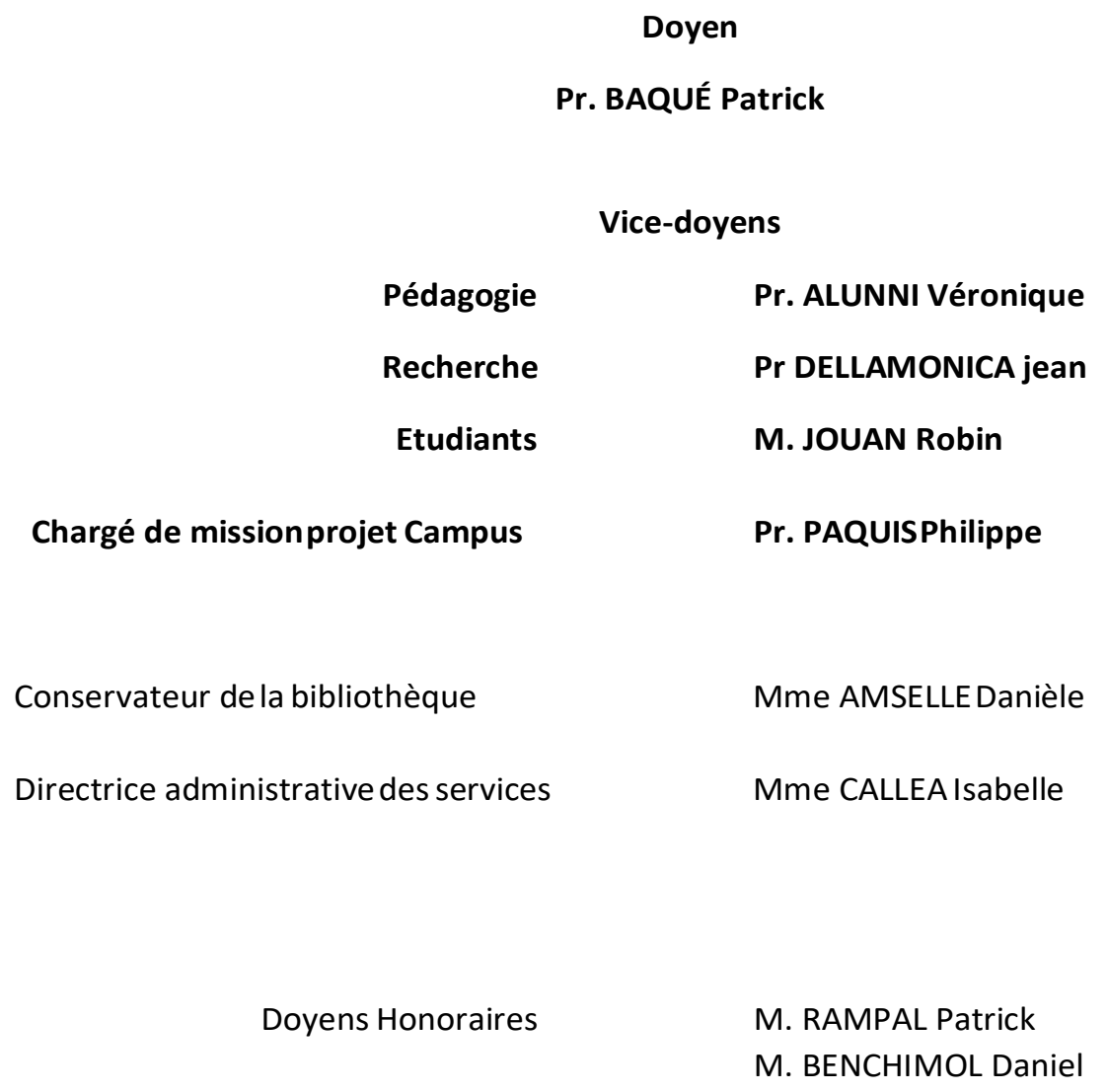




\begin{tabular}{|c|c|}
\hline M. & BAQUÉ Patrick \\
\hline M. & BERNARDIN Gilles \\
\hline Mme & BLANC-PEDEUTOUR Florence \\
\hline M. & BOILEAU Pascal \\
\hline M. & DARCOURT Jacques \\
\hline M. & DRICI Milou-Daniel \\
\hline M. & ESNAULT Vincent \\
\hline M. & FUZIBET Jean-Gabriel \\
\hline M. & GILSON Éric \\
\hline M. & GUGENHEIM Jean \\
\hline M. & HASSEN KHODJA Reda \\
\hline M. & HÉBUTERNE Xavier \\
\hline M. & HOFMAN Paul \\
\hline Mme & ICHAI Carole \\
\hline M. & LACOUR Jean-Philippe \\
\hline M. & LEFTHERIOTIS Georges \\
\hline M. & MARQUETTE Charles-Hugo \\
\hline M. & MARTY Pierre \\
\hline M. & MICHIELS Jean-François \\
\hline M. & MOUROUX Jérôme \\
\hline Mme & PAQUIS Véronique \\
\hline M. & PAQUIS Philippe \\
\hline M. & PRADIER Christian \\
\hline M. & QUATREHOMME Gérald \\
\hline M. & RAUCOULES-AIMÉ MarC \\
\hline M. & ROBERT Philippe \\
\hline M. & SCHNEIDER Stéphane \\
\hline M. & THYSS Antoine \\
\hline M. & TRAN Albert \\
\hline
\end{tabular}

Anatomie - Chirurgie Générale (42.01)

Réanimation Médicale (48.02)

Cancérologie - Génétique (47.02)

Chirurgie Orthopédique et Traumatologique (50.02)

Biophysique et Médecine Nucléaire (43.01)

Pharmacologie Clinique (48.03)

Néphrologie (52-03)

Médecine Interne (53.01)

Biologie Cellulaire (44.03)

Chirurgie Digestive (52.02)

Chirurgie Vasculaire (51.04)

Nutrition (44.04)

Anatomie et Cytologie Pathologiques (42.03)

Anesthésiologie et Réanimation Chirurgicale (48.01)

Dermato-Vénéréologie (50.03)

Chirurgie vasculaire ; médecine vasculaire (51.04)

Pneumologie (51.01)

Parasitologie et Mycologie (45.02)

Anatomie et Cytologie Pathologiques (42.03)

Chirurgie Thoracique et Cardiovasculaire (51.03)

Génétique (47.04)

Neurochirurgie (49.02)

Épidémiologie, Économie de la Santé et Prévention (46.01)

Médecine Légale et Droit de la Santé (46.03)

Anesthésie et Réanimation Chirurgicale (48.01)

Psychiatrie d'Adultes (49.03)

Nutrition (44.04)

Cancérologie, Radiothérapie (47.02)

Hépato Gastro-entérologie (52.01) 


$\begin{array}{ll}\text { Mme } & \text { ASKENAZY-GITTARD Florence } \\ \text { M. } & \text { BARRANGER Emmanuel } \\ \text { M. } & \text { BÉRARD Étienne } \\ \text { M. } & \text { BONGAIN André } \\ \text { Mme } & \text { BREUIL Véronique } \\ \text { M. } & \text { CASTILLO Laurent } \\ \text { M. } & \text { CHEVALLIER Patrick } \\ \text { M. } & \text { DE PERETTI Fernand } \\ \text { M. } & \text { FERRARI Émile } \\ \text { M. } & \text { FERRERO Jean-Marc } \\ \text { M. } & \text { FONTAINE Denys } \\ \text { M. } & \text { GIBELIN Pierre } \\ \text { M. } & \text { HANNOUN-LEVI Jean-Michel } \\ \text { M. } & \text { LEVRAUT Jacques } \\ \text { M. } & \text { LONJON Michel } \\ \text { M. } & \text { MOUNIER Nicolas } \\ \text { M. } & \text { PADOVANI Bernard } \\ \text { M. } & \text { PASSERON Thierry } \\ \text { M. } & \text { PICHE Thierry } \\ \text { Mme } & \text { RAYNAUD Dominique } \\ \text { M. } & \text { ROSENTHAL Éric } \\ \text { M. } & \text { STACCINI Pascal } \\ \text { M. } & \text { THOMAS Pierre } \\ \text { M. } & \text { TROJANI Christophe } \\ & \end{array}$

Pédopsychiatrie (49.04)

Gynécologie Obstétrique (54.03)

Pédiatrie (54.01)

Gynécologie-Obstétrique (54.03)

Rhumatologie (50.01)

O.R.L. (55.01)

Radiologie et Imagerie Médicale (43.02)

Anatomie-Chirurgie Orthopédique (42.01)

Cardiologie (51.02)

Cancérologie ; Radiothérapie (47.02)

Neurochirurgie (49.02)

Cardiologie (51.02)

Cancérologie ; Radiothérapie (47.02)

Médecine d'urgence (48.05)

Neurochirurgie (49.02)

Cancérologie, Radiothérapie (47.02)

Radiologie et Imagerie Médicale (43.02)

Dermato-Vénéréologie (50-03)

Gastro-entérologie (52.01)

Hématologie (47.01)

Médecine Interne (53.01)

Biostatistiques et Informatique Médicale (46.04)

Neurologie (49.01)

Chirurgie Orthopédique et Traumatologique (50.02) 


$\begin{array}{ll}\text { Mme } & \text { ALUNNI Véronique } \\ \text { M. } & \text { ANTY Rodolphe } \\ \text { M. } & \text { BAHADORAN Philippe } \\ \text { Mme } & \text { BAILLIF Stéphanie } \\ \text { Mme } & \text { BANNWARTH Sylvie } \\ \text { M. } & \text { BENIZRI Emmanuel } \\ \text { M. } & \text { BENOIT Michel } \\ \text { M. } & \text { BERTHET Jean-Philippe } \\ \text { M. } & \text { BOZEC Alexandre } \\ \text { M. } & \text { BREAUD Jean } \\ \text { Mme } & \text { BUREL-VANDENBOS Fanny } \\ \text { M. } & \text { CHEVALIER Nicolas } \\ \text { Mme } & \text { CHINETTI Giulia } \\ \text { M. } & \text { CLUZEAU Thomas } \\ \text { M. } & \text { DELLAMONICA Jean } \\ \text { M. } & \text { DELOTTE Jérôme } \\ \text { M } & \text { FAVRE Guillaume } \\ \text { M. } & \text { FOURNIER Jean-Paul } \\ \text { Mme } & \text { GIORDANENGO Valérie } \\ \text { Mme } & \text { GIOVANNINI-CHAMI Lisa } \\ \text { M. } & \text { GUÉRIN Olivier } \\ \text { M. } & \text { IANNELLI Antonio } \\ \text { M. } & \text { ILIE Marius } \\ M & \text { JEAN BAPTISTE Elixène } \\ \text { M. } & \text { ROHRLICH Pierre } \\ \text { M. } & \text { ROUX Christian } \\ \text { M. } & \text { RUIMY Raymond } \\ \text { Mme } & \text { SACCONI Sabrina } \\ \text { M. } & \text { SADOUL Jean-Louis } \\ \text { M. } & \text { VANBIERVLIET Geoffroy } \\ & \end{array}$

Médecine Légale et Droit de la Santé (46.03)

Gastro-entérologie (52.01)

Cytologie et Histologie (42.02)

Ophtalmologie (55.02)

Génétique (47.04)

Chirurgie Générale (53.02)

Psychiatrie (49.03)

Chirurgie Thoracique (51-03)

ORL- Cancérologie (47.02)

Chirurgie Infantile (54-02)

Anatomie et Cytologie pathologiques (42.03)

Endocrinologie, Diabète et Maladies Métaboliques (54.04)

Biochimie-Biologie Moléculaire (44.01)

Hématologie (47.01)

réanimation médicale (48.02)

Gynécologie-obstétrique (54.03)

Néphrologie (44-02)

Thérapeutique (48-04)

Bactériologie-Virologie (45.01)

Pédiatrie (54.01)

Méd. In ; Gériatrie (53.01)

Chirurgie Digestive (52.02)

Anatomie et Cytologie pathologiques (42.03)

Chirurgie vasculaire (51.04)

Pédiatrie (54.01)

rhumatologie (50.01)

Bactériologie-virologie (45.01)

Neurologie (49.01)

Endocrinologie, Diabète et Maladies Métaboliques (54.04)

Gastro-entérologie (52.01) 


\section{Liste des enseignants au 1er septembre 2019 à la Faculté de Médecine de Nice}

\section{MAITRES DE CONFÉRENCES DES UNIVERSITÉS - PRATICIENS HOSPITALIERS}

$\begin{array}{ll}\text { M. } & \text { AMBROSETTI Damien } \\ \text { Mme } & \text { BERNARD-POMIER Ghislaine } \\ \text { M. } & \text { BRONSARD Nicolas } \\ \text { M. } & \text { CAMUZARD Olivier } \\ \text { Mme } & \text { CONTENTI-LIPRANDI Julie } \\ \text { M. } & \text { DOGLIO Alain } \\ \text { M } & \text { DOYEN Jérôme } \\ \text { M. } & \text { FOSSE Thierry } \\ \text { M. } & \text { GARRAFFO Rodolphe } \\ \text { Mme } & \text { HINAULT Charlotte } \\ \text { M. } & \text { HUMBERT Olivier } \\ \text { Mme } & \text { LAMY Brigitte } \\ \text { Mme } & \text { LONG-MIRA Elodie } \\ \text { Mme } & \text { MAGNIÉ Marie-Noëlle } \\ \text { M. } & \text { MASSALOU Damien } \\ \text { Mme } & \text { MOCERI Pamela } \\ \text { M. } & \text { MONTAUDIE Henri } \\ \text { Mme } & \text { MUSSO-LASSALLE Sandra } \\ \text { M. } & \text { NAÏMI Mourad } \\ \text { Mme } & \text { POMARES Christelle } \\ \text { M. } & \text { SAVOLDELLI Charles } \\ \text { Mme } & \text { SEITZ-POLSKI barbara } \\ \text { M. } & \text { SQUARA Fabien } \\ \text { M. } & \text { TESTA Jean } \\ \text { Mme } & \text { THUMMLER Susanne } \\ \text { M. } & \text { TOULON Pierre } \\ & \end{array}$

Cytologie et Histologie (42.02) Immunologie (47.03)

Anatomie Chirurgie Orthopédique et Traumatologique (42.01)

Chirurgie Plastique (50-04)

Médecine d'urgence ( 48-04)

Bactériologie-Virologie (45.01)

Radiothérapie (47.02)

Bactériologie-Virologie-Hygiène (45.01)

Pharmacologie Fondamentale (48.03)

Biochimie et biologie moléculaire (44.01)

Biophysique et Médecine Nucléaire (43.01)

Bactérilogie-virologie ( 45.01)

Cytologie et Histologie (42.02)

Physiologie (44.02)

Chirurgie Viscérale ( 52-02)

Cardiologie (51.02)

Dermatologie (50.03)

Anatomie et Cytologie pathologiques (42.03)

Biochimie et Biologie moléculaire (44.01)

Parasitologie et mycologie (45.02)

Chirurgie maxillo-faciale et stomatologie (55.03)

Immunologie (47.03)

Cardiologie (51.02)

Épidémiologie Économie de la Santé et Prévention (46.01)

Pédopsychiatrie ( 49-04)

Hématologie et Transfusion (47.01) 
M. DARMON David

Mme GROS Auriane

PROFESSEURS AGRÉGÉS

Mme LANDI Rebecca

Anglais Orthophonie (69)

M. DURAND Matthieu

Urologie (52.04)

M. SICARD Antoine

Néphrologie (52-03)

PROFESSEURS ASSOCIÉS

M. GARDON Gilles

Médecine Générale (53.03)

Mme MONNIER Brigitte

Médecine Générale (53.03)

MAITRES DE CONFÉRENCES ASSOCIÉS

Mme CASTA Céline

Médecine Générale (53.03)

M. GASPERINI Fabrice

Médecine Générale (53.03)

M. HOGU Nicolas

Médecine Générale (53.03) 


\section{AMIEL Jean}

M ALBERTINI Marc

M. BALAS Daniel

M. BATT Michel

M. BLAIVE Bruno

M. BOQUET Patrice

M. BOURGEON André

M. BOUTTÉ Patrick

M. BRUNETON Jean-Noël

Mme BUSSIERE Françoise

M. CAMOUS Jean-Pierre

M. CANIVET Bertrand

M. CASSUTO Jill-patrice

M. CHATEL Marcel

M. COUSSEMENT Alain

Mme CRENESSE Dominique

M. DARCOURT GUY

M. DELLAMONICA Pierre

M. DELMONT Jean

M. DEMARD François

M. DESNUELLE Claude

M. DOLISI Claude

Mme EULLER-ZIEGLER Liana

M. FENICHEL Patrick

$M$. FRANCO Alain

M. FREYCHET Pierre

\section{M.C.U. Honoraires}

M. GASTAUD Pierre

M. GÉRARD Jean-Pierre

M. GILLET Jean-Yves

M. GRELLIER Patrick

M. GRIMAUD Dominique

M. HOFLIGER Philippe

M. JOURDAN Jacques

M. LAMBERT Jean-Claude

M. LAZDUNSKI Michel

M. LEFEBVRE Jean-Claude

M. LE FICHOUX Yves

Mme LEBRETON Elisabeth

M. MARIANI Roger

M. MASSEYEFF René

M. MATTEI Mathieu

M. MOUIEL Jean

Mme MYQUELMartine

M. ORTONNE Jean-Paul

M. PRINGUEY Dominique

M. SANTINI Joseph

M. SAUTRON Jean Baptiste

M. SCHNEIDER Maurice

$M$. TOUBOL Jacques

M. TRAN Dinh Khiem

$M$ VAN OBBERGHEN Emmanuel

M. ZIEGLER Gérard
M. ARNOLD Jacques
M. BASTERIS Bernard
M. BENOLIEL José
Mlle CHICHMANIAN Rose-Marie
Mme DONZEAU Michèle
M. EMILIOZZI Roméo
M. FRANKEN Philippe
M. GASTAUD Marcel

\author{
M. GIUDICELLI Jean \\ M. MAGNÉ Jacques \\ Mme MEMRAN Nadine \\ M. MENGUAL Raymond \\ M. PHILIP Patrick \\ M. POIRÉE Jean-Claude \\ Mme ROURE Marie-Claire
}




\section{REMERCIEMENTS}

À Monsieur le Professeur Marc RAUCOULES-AIMÉ,

Vous me faites l'honneur de présider ce jury et de juger ce travail. Soyez assuré de mes remerciements et de ma respectueuse considération.

À Monsieur le Professeur Patrick BAQUÉ, Vous me faites l'honneur de juger ce travail. Veuillez trouver ici l'assurance de ma sincère reconnaissance.

À Madame le Professeur Brigitte MONNIER,

Merci d'avoir accepté de juger ce travail et merci de l'enseignement que vous m'avez apporté en tant que tutrice au cours de mes premières années d'internat. Veuillez croire en ma respectueuse considération.

À Monsieur le Professeur GARDON Gilles, Je vous remercie de l'intérêt que vous avez porté à ce sujet de thèse. Je vous adresse toute ma reconnaissance.

À Monsieur le Docteur TÉTART Johann, Merci d'avoir participé à l'initiation de ce projet et pour le temps passé lors des réunions téléphoniques. Aie l'assurance de ma sincère reconnaissance.

À Monsieur le Docteur BARBAROUX Adriaan, Tu me fais I'honneur d'avoir accepté de diriger ce travail. Je te remercie sincèrement pour ton accompagnement si précieux. Merci pour la disponibilité dont tu as fait preuve. Merci d'avoir été à l'écoute de mes peurs, de mes doutes et d'avoir su me motiver même lorsque j'étais à l'autre bout du monde. Je ne pouvais trouver meilleur directeur de thèse.

À Marion, ma co-thésarde, je suis contente d'avoir fait ce travail avec toi. Merci d'avoir partagé tous ces moments de doutes, de joie, de travail, de réunions téléphoniques. J'aime tes valeurs et tes convictions, ne change pas.

Thank you, Françoise for your valuable advices.

À tous les médecins qui ont participé à cette étude, pour le temps que vous avez consacré à mon travail.

Aux médecins qui ont croisé ma route et qui ont parfois sans le savoir orienté mon parcours professionnel :

Au Professeur ALLARD Michel, pour avoir fait naître en moi l'envie de devenir médecin. Au Docteur LECERF Éric, pour m'avoir transmis le goût de la médecine générale alors que je ne m'y prédestinais pas. Merci pour cette belle expérience.

Au Docteur BARBE Chantal, pour l'enseignement apporté. Tu es à mes yeux un modèle d'accomplissement professionnel et personnel. 
Au Docteur DANDURAN Marie et DIEBOLT Vincent, ainsi qu'à toute l'équipe de la maison de santé de Valdeblore (en particulier Carine et Annabelle), pour leur accueil, leur sympathie et leur apprentissage.

Au Docteur LION Odile, merci pour ta confiance et ton enseignement.

\section{À mes proches :}

À mes parents qui me couvrent depuis des années de leur amour, malgré mes sautes d'humeur parfois. Merci pour cette enfance parfaite. Maman, je suis contente de pouvoir aussi bien discuter avec toi. Papa, je te remercie pour les devoirs du soir dans le jardin, je te dois tous mes " exploits" sportifs et merci de m'avoir appris que la défaite n'était pas une fatalité.

À ma petite sœur chérie, dont j'admire le parcours aussi bien professionnel que personnel. Je suis tellement fière de toi, ma juju. Je t'aime énormément. J'ai hâte de me rapprocher de vous et de vous voir plus souvent, Mathis et toi.

À mes grands-parents, mes oncles, mes tantes, mes cousins et cousines pour leur amour et leur soutien, avec une pensée plus particulière pour mon oncle Éric. Merci à Mamie Ginette pour sa relecture, à Papi Guy et à tata Isa d'avoir fait le trajet jusqu'ici, j'espère vous rendre fiers.

À ma belle-famille, qui me supporte depuis près de 8 ans. J'ai vraiment de la chance d'avoir une belle-famille comme la vôtre. Je ne pouvais rêver mieux. Merci pour tout.

À Alice G, ma presque jumelle, merci pour ton amitié si précieuse et ton soutien depuis 28 ans. Je suis contente et si fière de t'avoir à mes côtés. J'aime te savoir heureuse avec Julien, même si le Ch'Nord c'est un peu loin. À Aude, qui depuis mes 15 ans me comble de joie, de rire et d'amour. J'ai hâte de pouvoir être à vos côtés, Pipo et toi, l'été prochain. Vous avoir à mes côtés aujourd'hui est le plus beau cadeau que vous puissiez me faire.

À Pauline, sans qui je ne serais pas là aujourd'hui. Tu m'as apporté l'équilibre dont j'avais besoin pour réussir cette première année. Je suis très fière de la femme et de l'infirmière que tu es devenue. Je suis contente de te savoir auprès de moi en ce jour.

À Chloé, ma cloque, parce qu'il y a des amitiés évidentes et qui le reste même à des kilomètres. Ta présence ce jour en est la preuve, mille mercis.

À Hélène et Quentin A-D, loin des yeux, si près du cœur. Merci de tout cœur d'être là.

À Justine, merci d'avoir été une coloc parfaite. Merci pour tous ces moments de rires, de pleurs, de danses, de chants parfois faux. Avoir été plantouriane avec toi a été un vrai régal.

À Audrey et Quentin, je suis tellement heureuse de vous avoir suivis dans cette aventure qu'est l'internat pour prolonger cette belle amitié. J'espère avoir été à la hauteur pour votre grand jour.

À Lyor, on part mais on ne t'abandonne pas. Prends le bon côté de la vie, ne lui casse pas les côtes, tu auras ta chambre, un jour, sur la Côte Ouest ! Je ferai tout pour ne pas faire mourir ton lierre, promis.

À Alice $B$, ma deuxième petite sœur, à qui je pense souvent.

À Anne, j'ai hâte de venir te rendre visite de nouveau à Nantes.

À Guigui, mon oncle de cœur. 
Aux amis de longue date : la MIF : Marie, Ana, Laura, Mel, Célia, Caro, Alex, Jérem, Cougn, Breb, Chach, Guigui, Clément et leurs valeurs ajoutées, les copines d'enfance : Noémie, Natacha et Adèle.

Aux pictaviens, Quentin F, Camille et leurs petits bouts, Pierre et Maëlle, Arthur et Alice, Julie et Thomas, Sylvain et Lucia, Éric (même s'il n'aime pas mes pantalons de voyage) et Élisa, Coco et ses coconades, pour leur amitié si précieuse.

À la coloc du Fango, aux bons moments passés.

À ma Carinette, une des plus belles rencontres au cours de mon internat. Je suis tellement fière de toi pour ta formation d'IPA. Je te souhaite de réussir et de t'épanouir dans cette nouvelle voie.

À Loïc, merci d'être à mes côtés depuis presque huit ans. Merci de me faire rire comme au premier jour. Merci de me comprendre quand je perds mes clés, que je loupe des trains et que j'oublie mes cartes bleues, mon sac à main... Merci de continuer à éveiller ma curiosité sur le monde qui nous entoure. J'ai hâte de poser enfin nos valises et de pouvoir surfer avec toi, afin d'être sûre que tu ne te casses rien, cette fois. Je suis heureuse de franchir cette nouvelle étape à tes côtés. Et même si je dis le contraire, je serai toujours là pour te courir après, autour du canapé si tu as besoin de Lovenox ${ }^{\circledR}$. Je t'aime. 


\section{TABLE DES MATIERES}

LISTE DES ABRÉVIATIONS :

RESUMÉ......................................................................... 15

INTRODUCTION .................................................................. 16

METHOD......................................................................... 17

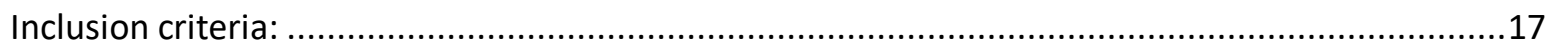

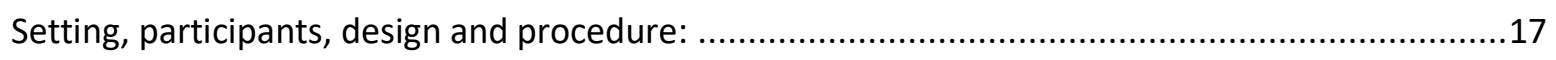

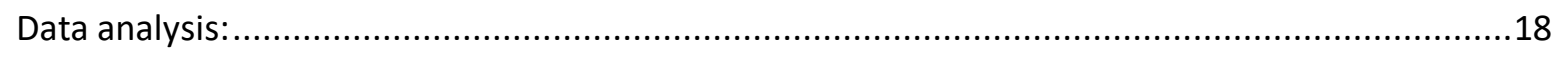

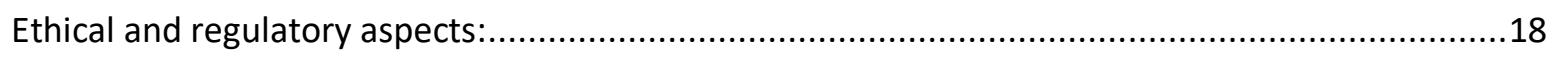

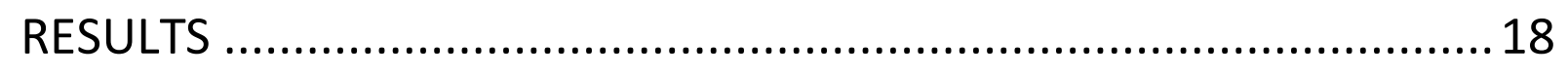

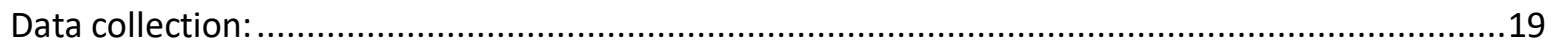

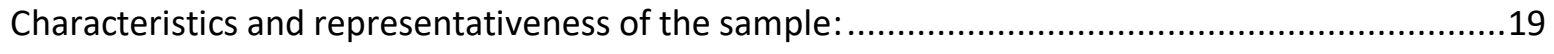

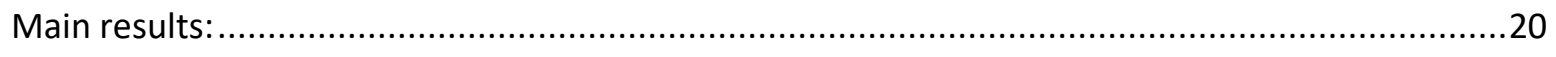

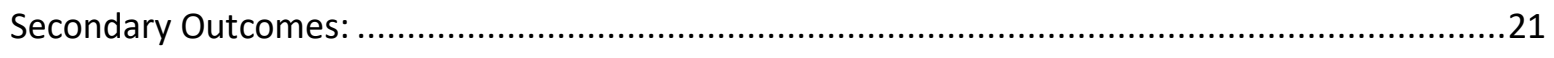

DISCUSSION.............................................................. 21

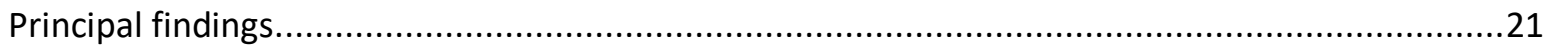

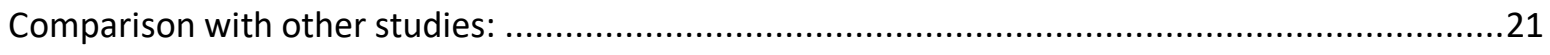

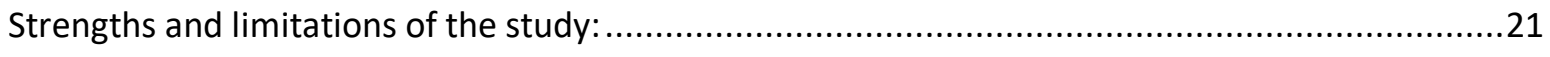

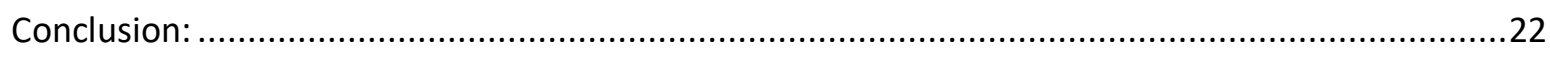

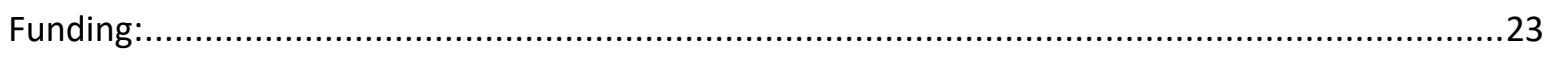

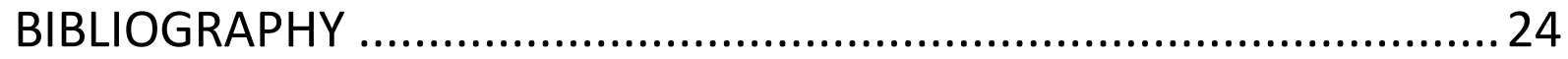

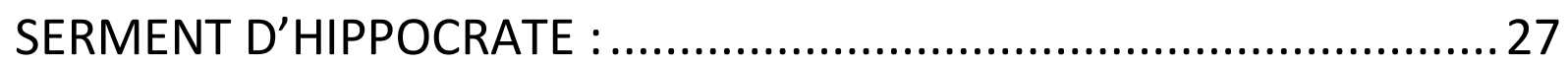

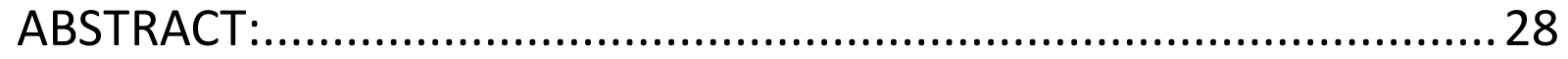




\section{LISTE DES ABRÉVIATIONS :}

CNIL : National Commission for Data Protection and Liberties, Comission Nationale de l'Informatique et des Libertés

DERMG : Département d'Enseignement et de Recherche en Médecine Générale

HAS: French National Authority for Health, Haute Autorité de Santé

GP(s): General Practitioner(s), médecin(s) généraliste(s)

IFH : French Hypnosis Institute, Institut Français d'Hypnose

INSERM : National Institute of Health and Medical Research, Institut National de la Santé Et de la Recherche Médicale

IUD : Inter-University Diploma, Diplôme Inter-Universitaire

LAPCOS : Laboratoire d'Anthropologie et de Psychologie Cliniques, cOgnitives et Sociales

ROSP : Compensation on Public Health Objectives, Rémunération sur Objectifs de Santé Publique

UD: University Diploma, Diplôme Universitaire 


\section{Training in medical hypnosis and prolonged use of benzodiazepines: The French National Health Insurance Data.}

Léa Légereau ${ }^{1}$, Marion Bonnard ${ }^{1}$, Johann Tétart ${ }^{1}$, Adriaan Barbaroux $^{2}$.

${ }^{1}$ Université Cote d'Azur, Rétines, DERMG, France

${ }^{2}$ Université Cote d'Azur, Rétines, LAPCOS, DERMG, France.

Article: 2613 words, 13820 characters.

Abstract: 273 words, 1563 characters. 


\section{RESUMÉ}

\section{Introduction :}

En France, les benzodiazépines sont largement prescrites et $15 \%$ de leurs instaurations sont prolongées hors des délais. La Haute Autorité de Santé (HAS, French National Authority for Health) recommande de privilégier des alternatives non médicamenteuses. L'hypnose pourrait être une de ces alternatives.

\section{Objectif :}

Évaluer les données de la Rémunération sur Objectifs de Santé Publique (ROSP) concernant le traitement par benzodiazépines hors délai chez les médecins généralistes (MG) formés en hypnothérapie.

\section{Méthodes :}

Une étude descriptive de cohorte a été menée de juin à décembre 2019. Les données de la ROSP des prescriptions en 2019 de médecins généralistes formés à l'hypnose, ont été recueillies. Les deux critères de jugement principaux étaient le taux de prescriptions hors délai par rapport au nombre total de prescriptions de benzodiazépines hypnotiques et anxiolytiques (critères ROSP).

\section{Résultats :}

189 médecins ont été contactés soit 30 \% de la population nationale des médecins généralistes formés à l'hypnose. Parmi les 189 médecins, seuls 81 exerçaient en libéral avec une convention. 24 n'ont pas pu être contacté et cinq ont refusé de répondre. Au total, 52 MG libéraux français sur un échantillon de 81 (64\%) ont été interrogés par téléphone ou courriel. La somme des patientèles étudiées représentait 52000 patients.

$38,3 \%$ des prescriptions d'hypnotiques et $14,8 \%$ des prescriptions d'anxiolytiques étaient prolongées hors délai pour des taux nationaux respectivement de $42.8 \%$ et $14,8 \%$, sans différence statistiquement significative.

\section{Conclusion :}

Le fort taux de participation et la taille de notre échantillon suggèrent que ces résultats sont représentatifs. La formation à I'hypnose n'est pas significativement corrélée à une meilleure prescription des hypnotiques ou des anxiolytiques. Une étude qualitative est en cours pour mieux comprendre ces résultats.

Mots-clés : Médecin Générale, Hypnose, Benzodiazépines hypnotiques et anxiolytiques. 


\section{INTRODUCTION}

latrogeny is a public health burden. The latest studies show that $10 \%$ of hospitalizations are due to iatrogeny $(1,2)$. Internationally, a New Zealand study shows that reducing the use of a single drug for the elderly reduces the number of hospital admissions (3). An American study shows that benzodiazepines increase the risk of readmission to hospital within 30 days(4). France is one of the five countries with the highest benzodiazepine and related drug use in Europe(5). $15 \%$ of new benzodiazepine introductions are extended beyond the recommended prescribing time(5). Prolonged use of benzodiazepines is particularly dangerous (6-8). The National Health System has set up a process to improve prescriptions in general medicine: The Remuneration based on Public Health Objectives (ROSP, Rémunérations sur Objectifs de Santé Publique). This system represents an investment of 240 million euros per year(9). ROSP for benzodiazepines correspond to the percentage of patients on benzodiazepines hypnotics or anxiolytics prolonged outside the recommended range among patients treated with benzodiazepines. The maximum amount of ROSP for benzodiazepines is 490 euros per general practitioner (GP) per year, that means more than 25 million euros nationwide $(9,10)$. Unfortunately, studies show that the ROSP has few or no effect on GPs prescribing $(11,12)$. It is therefore necessary to find new aids to improve benzodiazepine prescribing.

Hypnosis could be an aid in limiting these prescriptions outside the recommended time limits(13). Hypnosis is a 200-year-old technique that uses speech to induces a specific state of consciousness characterized by indifference to the outside world and a greatly increased ability to receive suggestions. Through these suggestions, the patient is supposed to find internal resources for fighting anxiety, pain(14), etc.

About ten medical universities in France offer a University Diploma (UD) in medical hypnosis accessible to GPs. According to a recent report of the National Institute of Health and Medical Research (INSERM, Institut National de la Santé Et de la Recherche Médicale), certain training courses guarantee quality practices (15). The one-year UDs delivered in the Faculty of Medicine as well as the French Hypnosis Institute (IFH) are part of this training. The IFH training has a reliable and recognized two-year course. Others are open to a wider public with variable ethics (15). If hypnosis is not yet recognized by the French Medical Board (16), some indications are now recognized. For example, hypnoanalgesia is considered to be a medical act (14). However, there is currently no reimbursement for hypnosis sessions.

There are few studies on hypnosis and often the samples are too small for the results to be significant $(17,18)$, hence the interest in conducting new studies with reliable methodologies. 
The objective of this study was to evaluate the impact of hypnosis training (UD and IFH) of GPs on the prescription of hypnotics and anxiolytics over the long term by GPs. This study was associated with a qualitative study which explores the perception of GPs in the Provence-Alpes-Côte d'Azur region on their hypnosis training and the way in which it is integrated into their practice, particularly on the management of insomnia.

\section{METHOD}

A descriptive observational study was conducted from June to December 2019 on GPs trained in hypnosis in France.

\section{Inclusion criteria:}

The inclusion criteria were as follows: liberal GPs practicing in France, trained in medical hypnosis by UD or IFH, working as liberals with a convention allowing access to ROSP data.

\section{Setting, participants, design and procedure:}

The Universities cited in the last INSERM study on medical hypnosis were contacted by telephone, email or directly via the faculty's website. Only five out of ten agreed to provide a list of their students: Bordeaux, Limoges, Nice, Paris VI and Reunion Island. Universities that did not respond favourably agreed to give an approximate number of GPs trained in hypnosis. This approximate number of trained GPs allowed the authors to know the size of the population of GPs trained in hypnosis by UDs or IFH, that is supposed to be around 500 GPs (Fig1). The lists given enabled to contact 129 GPs, which represents one third of the general practitioners trained by UD in France. All the GPs trained by the IFH were included (60).

A total of 189 GPs trained in hypnosis, 129 by UD and 60 by IFH, were contacted over a period from June to December 2019. GPs were surveyed by telephone or e-mail questionnaire on the main criteria for prescribing $(19,20)$ and on the percentage of out-of-time prescriptions of hypnotic and anxiolytic benzodiazepines based on Public Health Goals Compensation data, the ROSP. The telephone questionnaire lasted between three and five minutes. The items requested in the questionnaire were as follows: age, gender, length of time in practice, conventional sector (1 or 2), practice environment (rural, urban, semi-rural), average duration of general medical consultations, meeting pharmaceutical representatives or not, place of internship, year and place of training at the UD or IFH, the size of the GP's patients list, the number of GP's patients over 80 years of age and the percentages of prolonged prescriptions of hypnotics and anxiolytics (ROSP). The authors decided to use the percentages of prolonged prescriptions of hypnotics and anxiolytics in the Public Health Objective Remuneration (ROSP) of GPs trained in hypnosis to evaluate the prescription of benzodiazepines because the GPs themselves could access to their personal data on the national health insurance website and then 
transmit them or the investigator would perform the manoeuvre via the Team Viewer ${ }^{\oplus}$ remote control software.

To obtain a statistical power of $90 \%$ with a tolerated alpha risk of $5 \%, 53$ subjects were required, assuming $40.9 \%$ of prescriptions being continued over the long term in the general population against $20,4 \%$ in the hypnosis group. However, this a priori sample size calculation was made for information purposes only. The aim of this nationwide survey was to include as much hypnosis trained GPs as possible.

\section{Data analysis:}

The data collected was entered into an Excel $^{\circledR}$ spreadsheet and analysed using Jamovi ${ }^{\circledR}$ software(21,22). The One Sample Student T Test was used to analyse the sample after checking for normality using the Skewness, Kurtosis and Shapiro Wink tests.

The primary outcome of ROSP percentages of anxiolytic and hypnotic benzodiazepines were analysed by adjusting for gender, type of training or exercise setting. The secondary judgement criteria represented by the other questionnaire items were then examined by calculating a correlation matrix.

\section{Ethical and regulatory aspects:}

Patient and public involvement was not appropriate for this study. A statement MR-004 was made to the National Commission for Data Protection and Liberties (CNIL, Commission Nationale de I'Informatique et des Libertés). This type of study did not require the approval of an ethics committee.

\section{RESULTS}

Of the 189 GPs interviewed, 69 were working in hospitals and were therefore excluded (not concerned by the ROSP). Those with no ROSP due to the absence of agreement with the national health insurance or to retirement, replacement or still being a resident were also excluded (39). Of the remaining GPs meeting the inclusion criteria, 24 could not be contacted because they were missing in the directory and five declined to participate in the study. A total of $52 \mathrm{GPs}$ agreed to participate in this study out of the 81 liberal GPs trained in hypnosis who could have been included in this study (Fig 1.): 38 GPs trained by UD and 14 GPs trained by IFH.

The response rate of our sample was $64 \%$, mainly due to the absence of GPs in the repertoire. The response rate of our sample (liberal GPs listed in the directory and agreed by the national health insurance) was more than $91 \%$ (52 out of 57 ). Our sample is supposed to be the third of the total 
French population of GPs trained in hypnosis since the UD and IFH provided a list of 189 GPs and declared than 560 GPs were trained since the creation of the UD and IFH, respectively 2001 and 1990.

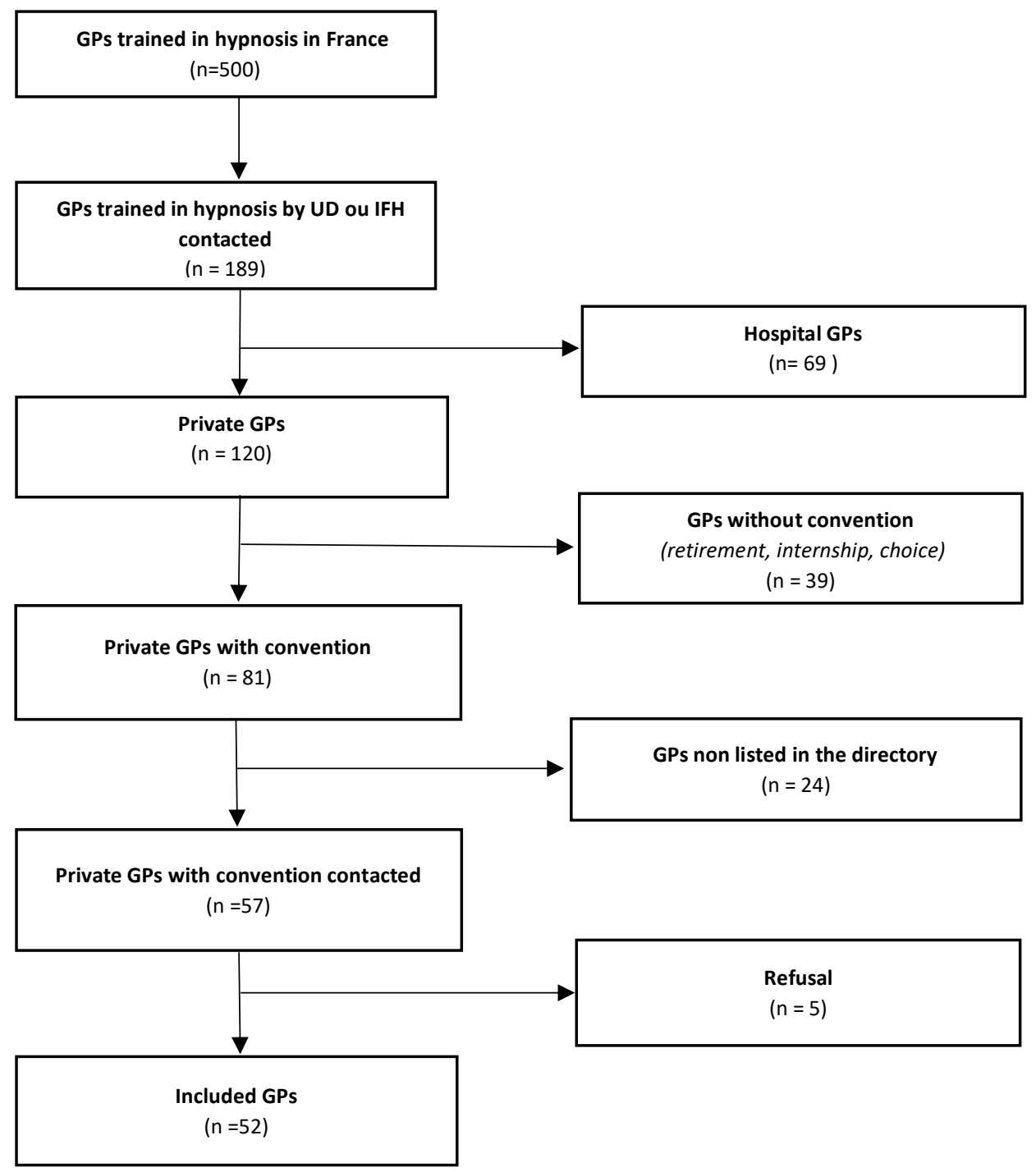

Fig 1. Flow chart

GPs: General practitioners, UD: University Diploma, IFH: French Hypnosis Institute

\section{Characteristics and representativeness of the sample:}

The average age of the GPs included was 51.3 (S.D. 9.7) years old, which is close to the average age of GPs (50.6 years) in France in 2018(23). The average age of GPs trained by the IFH was 56.6 years old, which can be explained by the fact that IFH was created in 1990 and UD were initiated in 2001.

Most of the GPs were charging the national health approved rate (also called "sector 1") (48 GPs), 4 GPs were charging extra fees ("sector 2"). The average number of patients on a GP's list was 1030, with an average of 63 patients aged over 80 years, i.e. $6 \%$ of the patients' population (see population 
characteristics in table 1). The average seniority of GPs in their practice was 18 years. The percentage of women was $50 \%$, which is close to French GPs population (23). The average age of women was slightly lower than the one of men, which is consistent with the recent feminization of the profession.

The place of practice of the GPs surveyed was predominantly urban at $50 \%$ (26 GPs), semi-rural at $29 \%$ (15 GPs) and rural at 21\% (11 GPs), in line with French medical demographics, which are predominantly urban(23,24).

\begin{tabular}{lrrrrr}
\hline & $\begin{array}{c}\text { Age (years- } \\
\text { old) }\end{array}$ & $\begin{array}{c}\text { Seniority } \\
\text { (years) }\end{array}$ & $\begin{array}{c}\text { Duration of } \\
\text { consultation (min) }\end{array}$ & $\begin{array}{c}\text { Patients } \\
\text { (n) }\end{array}$ & $\begin{array}{r}\text { Patient }>\mathbf{8 0} \\
\text { years of age } \\
\text { (nb) }\end{array}$ \\
\hline N & 52 & 52 & 52 & 52 & 52 \\
Missing & 0 & 0 & 0 & 0 & 0 \\
Mean & 51.3 & 18.4 & 18.8 & 1030 & 63.6 \\
Median & 53.0 & 20.0 & 15.0 & 1000 & 50.5 \\
Standard & 9.67 & 9.87 & 6.01 & 535 & 54.2 \\
deviation & 29 & 2.00 & 10 & 5 & 0 \\
Minimum & 71 & 35.0 & 45 & 2686 & 288 \\
Maximum & & & & & \\
\hline
\end{tabular}

Table 1 - Population characteristics.

*ROSP : Rémunération sur Objectifs de Santé Publique, Public Health Objective Remuneration.

\section{Main results:}

The public health target for the percentage of benzodiazepines is $30 \%$ for hypnotics and $9 \%$ for anxiolytics. The average percentage of benzodiazepine hypnotics in this sample was $38,3 \%$ (S.D. 20.2), below the national average of $42.4 \%$ in December 2019 but still above the targeted objective. The average ROSP data for Benzodiazepines Anxiolytics was $14.8 \%$ (S.D. 8.5), compared to a national average of $14.8 \%$, above the targeted objective too.

Statistical analysis using Student's T-test did not find a significant difference $(p=0.14)$ in prescribing between GPs trained in hypnosis and the general population of GPs ( $t-1.48,95 \%$ confidence interval 9.74 to 1.48$)$. There was also no significant difference $(p=0.97)$ in benzodiazepine prescribing (t 0.028 , $95 \%$ confidence interval $-2,41$ to 2,34 ). 


\section{Secondary Outcomes:}

No significant correlation was found between Benzodiazepines prescriptions and the age, the gender of the GP the seniority of his installation, his environment of practice (rural, urban, semi-rural), the average duration of the consultations of general medicine, the visit or not of laboratory, the fact to charge extra fees or not (sector 1 or 2), the place of his internship, the year and the kind of training (UD or IFH).

\section{DISCUSSION}

\section{Principal findings:}

These data showed that GPs trained in medical hypnosis were not significantly better prescribers for benzodiazepine hypnotics or anxiolytics than GPs in general. These non-significant results are fairly consistent with the often inconclusive statistical studies about hypnosis $(17,18,25)$, but this is the first time ever a study of this magnitude has been conducted.

\section{Comparison with other studies:}

The correlation of the data showed significantly that an elderly population was not synonymous with a benzodiazepine-dependent population, contrary to data in the literature. Fourrier et al have shown that elderly subjects were heavy benzodiazepine users (26). Our data did not find any correlation between the mean patients list of a GP and his proportion of prolonged benzodiazepines prescription. Prescribing of benzodiazepines in this study is not correlated with numbers of laboratory visits, unlike the literature which tends to show that GPs receiving medical sales representatives are heavy prescribers(27-29). This discrepancy can be explained by the fact that the rate of GPs not receiving medical sales representatives in this study was much higher than the national average $(44 \%$ vs $25 \%)(30)$.

\section{Strengths and limitations of the study:}

The response rate of our sample was extremely high, since 52 of the 57 GPs who met all the inclusion criteria agreed to respond to this study, i.e. $91 \%$ of the sample. Since the sample corresponds to one third of the GPs trained in France, our sample is probably highly representative of the population of GPs trained by UD and IFH, the two courses which guarantee quality practices (15) according to the National Institute of Health and Medical Research (INSERM, Institut National de la Santé Et de la Recherche Médicale). The high response rate was partly due to the speed of the questionnaire and the ease of access to the ROSP data, directly accessible by the practitioner on his personal space on the National Health Insurance website. 
The GP characteristics relatively close to those of the general population and the number of GPs included suggest that this study is representative. The number of GPs trained in hypnosis is low: $1 \%$ of the French general practitioner population. In comparison, $2.6 \%$ of French GPs received palliative care IUD (Inter-University Diploma) between 2005 and 2009(31).

This study was carried out in conjunction with a qualitative study on hypnosis training for GPs in the Provence-Alpes-Côte d'Azur region and its influence on their prescriptions, particularly in the context of insomnia. These data showed that medical hypnosis is seen as an aid in the management of insomnia(32). The few qualitative theses on hypnosis also showed a downward trend in therapeutics $(33,34)$.

The primary outcome (ROSP percentages) are quite controversial. There are many confounding factors on these data. The method of calculation can also lead to bias: a GP prescribing very few benzodiazepines but who has these few patients out of time will have a higher percentage than a GP prescribing many benzodiazepines but most within the recommended time frame, even with the same number of patients out of time. However, this criterion is sufficiently reliable to be recognised by the National Health Insurance as representing good prescribing by GPs in the context of ROSP. Indeed, prescribing benzodiazepines for a short duration is not necessarily problematic, the most problematic situation is long term prescription(8). Therefore, this criterion seems relevant. However, it might be interesting to evaluate the number of patients treated with benzodiazepines in order to put these percentages in the context of the number of prescriptions.

Another limitation could be the risk of a reporting bias when GPs were asked to report their ROSPS data. Asking GPs to provide a screenshot of the National Health Insurance website would have helped to limit this bias. However, it was chosen to keep this data declarative in order to preserve the short duration of the interviews with the GPs, which allowed a remarkably high response rate.

\section{Conclusion:}

Overall, the present study has shown that GPs trained in hypnosis were no better prescribers of benzodiazepines than untrained GPs in terms of prescription duration. Hypnosis is a therapy that varies from one individual to another, both in terms of indication and method $(35,36)$, which does not allow generalisation and makes it difficult to develop significant studies $(15,17,18)$. The qualitative study carried out jointly has shown that trained GPs used hypnosis to manage insomnia and considered hypnosis as helpful. In that study, GPs said that results for insomnia were variable from one patient to another. Some patients had a better sleep after few hypnosis sessions, but few others felt no effect of hypnosis. The present study is probably the largest study conducted on GPs trained in hypnosis in 
primary care. This study did not show any difference in the long-term/short-term benzodiazepine prescription ratio between trained GPs and non-trained GPs.

\section{Funding:}

This research received no specific grant from any funding agency in the public, commercial or not-forprofit sectors. 


\section{BIBLIOGRAPHY}

1. Caulin $C$, Vittecoq $D$. Mise au point : Prévenir la iatrogénèse médicamenteuse chez le sujet âgé, [Internet]. AFSSAPS, éditeur. 2005. Disponible sur:

file://C:/Users/leale/Zotero/storage/G4Z8B32Y/iatrog\%C3\%A9n\%C3\%A8se\%20m\%C3\%A9dicam enteuse.pdf

2. Sourdet S, Lafont $C$, Rolland $Y$, Nourhashemi F, Andrieu S, Vellas B. Preventable latrogenic Disability in Elderly Patients During Hospitalization. J Am Med Dir Assoc. août 2015;16(8):674-81.

3. Ailabouni N, Mangin D, Nishtala PS. Deprescribing anticholinergic and sedative medicines: protocol for a Feasibility Trial (DEFEAT-polypharmacy) in residential aged care facilities. BMJ Open. avr 2017;7(4):e013800.

4. Pavon JM, Zhao Y, McConnell E, Hastings SN. Identifying Risk of Readmission in Hospitalized Elderly Adults Through Inpatient Medication Exposure. J Am Geriatr Soc. juin 2014;62(6):1116-21.

5. Richard N. Etat des lieux de la consommation des benzodiazépines en France. Agence Nationale de Sécurité du Médicament et des produits de santé, ANSM. avr 2017;60.

6. Holbrook AM, Crowther R, Lotter A, Cheng C, King D. Meta-analysis of benzodiazepine use in the treatment of insomnia. CMAJ Can Med Assoc J. 25 janv 2000;162(2):225-33.

7. Neutel $\mathrm{Cl}$. The epidemiology of long-term benzodiazepine use. Int Rev Psychiatry. janv 2005;17(3):189-97.

8. Gage SB de, Moride $\mathrm{Y}$, Ducruet $\mathrm{T}$, Kurth $\mathrm{T}$, Verdoux $\mathrm{H}$, Tournier M, et al. Benzodiazepine use and risk of Alzheimer's disease: case-control study. BMJ [Internet]. 9 sept 2014 [cité 4 févr 2020];349. Disponible sur: https://www.bmj.com/content/349/bmj.g5205

9. CNAM_-_Dossier_de_presse_Rosp_2017_-_25_Avril_2018.pdf [Internet]. [cité 12 févr 2020]. Disponible sur: https://www.ameli.fr/fileadmin/user_upload/documents/CNAM__Dossier_de_presse_Rosp_2017_-_25_Avril_2018.pdf

10. Rosp médecin traitant de l'adulte [Internet]. [cité 12 févr 2020]. Disponible sur: https://www.ameli.fr/medecin/exercice-liberal/remuneration/remuneration-objectifs/medecintraitant-adulte

11. Rat C, Penhouet G, Gaultier A, Chaslerie A, Pivette J, Nguyen JM, et al. Did the new French payfor-performance system modify benzodiazepine prescribing practices? BMC Health Serv Res. 11 juill 2014;14:301.

12. Scott A, Sivey P, Ait Ouakrim D, Willenberg L, Naccarella L, Furler J, et al. The effect of financial incentives on the quality of health care provided by primary care physicians. Cochrane Effective Practice and Organisation of Care Group, éditeur. Cochrane Database Syst Rev [Internet]. 7 sept 2011 [cité 14 févr 2020]; Disponible sur: http://doi.wiley.com/10.1002/14651858.CD008451.pub2

13. Raineri et al. - 1997 - hypnose L’hypnose en consultation.pdf [Internet]. [cité 24 mai 2018]. Disponible sur: 
http://www.sfmg.org/data/generateur/generateur_fiche/1149/fichier_fichier_dr49_raineria14a a.pdf

14. fiche_hypnose_2016.pdf [Internet]. [cité 14 févr 2020]. Disponible sur: https://solidaritessante.gouv.fr/IMG/pdf/fiche_hypnose_2016.pdf

15. Gueguen J, Barry C, Hassler C, Falissard B. Evaluation de l'efficacité de la pratique de l'hypnose. Institut National de la Santé Et de la Recherche Médicale, INSERM. juin 2015;213.

16. Ordre des médecins - Webzine $n^{\circ} 3$ [Internet]. [cité 14 févr 2020]. Disponible sur: https://www.conseil-national.medecin.fr/sites/default/files/external-package/webzine/201507/www/index.html\#/page-2

17. Ng B-Y, Lee T-S. Hypnotherapy for Sleep Disorders. 2008;37(8):6.

18. Pelissolo A. L'hypnose dans les troubles anxieux et phobiques : revue des études cliniques. /data/revues/07554982/v45i3/S0755498215005722/ [Internet]. 15 avr 2016 [cité 10 juin 2018]; Disponible sur: http://www.em-consulte.com/en/article/1048355\#N100D8

19. Faurie A. Les déterminants du renouvellement des benzodiazépines et apparentées au - delà de trois mois. Thèse de médecine : Université de Poitiers, 16 janv 2004, " dactyl ", 68.

Une étude quantitative auprès de 187 médecins généralistes de Poitou - Charentes . [Internet]. [cité 21 janv 2019]. Disponible sur: http://nuxeo.edel.univpoitiers.fr/nuxeo/site/esupversions/4cc2ae56-f8c8-4823-8794-ba1d04f5764e

20. Élise AMAR et Céline PEREIRA. Les prescriptions des médecins généralistes et leurs déterminants. DREES - Dir Rech Etudes Eval Stat. 2005;12.

21. The jamovi project (2020). jamovi. (Version 1.2) [Computer Software]. Retrieved from https://www.jamovi.org. R Core Team (2019). R: A Language and envionment for statistical computing. (Version 3.6) [Computer software]. Retrieved from https://cran.r-project.org/.

22. R Core Team (2019). R: A Language and envionment for statistical computing. (Version 3.6) [Computer software]. Retrieved from https://cran.r-project.org/.

23. cnom_atlas_2018_0.pdf [Internet]. [cité 30 janv 2020]. Disponible sur: https://www.conseilnational.medecin.fr/sites/default/files/externalpackage/analyse_etude/hb1htw/cnom_atlas_2018_0.pdf

24. La demographie medicale a l'horizon 2030 : de nouvelles projections nationales et regionales. J Pédiatrie Puériculture. juill 2009;22(4-5):245-53.

25. Lam T-H, Chung K-F, Yeung W-F, Yu BY-M, Yung K-P, Ng TH-Y. Hypnotherapy for insomnia: A systematic review and meta-analysis of randomized controlled trials. Complement Ther Med. oct 2015;23(5):719-32.

26. Fourrier A, Letenneur L, Dartigues J, Moore N, Bégaud B. Benzodiazepine use in an elderly community-dwelling population: Characteristics of users and factors associated with subsequent use. Eur J Clin Pharmacol. août 2001;57(5):419-25.

27. Cormack MA, Howells E. Factors linked to the prescribing of benzodiazepines by general practice principals and trainees. Fam Pract. déc 1992;9(4):466-71. 
28. Wazana A. Physicians and the pharmaceutical industry: is a gift ever just a gift? JAMA. 19 janv 2000;283(3):373-80.

29. Spurling GK, Mansfield PR, Montgomery BD, Lexchin J, Doust J, Othman N, et al. Information from Pharmaceutical Companies and the Quality, Quantity, and Cost of Physicians' Prescribing: A Systematic Review. PLoS Med [Internet]. 19 oct 2010 [cité 27 avr 2020];7(10). Disponible sur: https://www.ncbi.nlm.nih.gov/pmc/articles/PMC2957394/

30. premier_bilan_certif_vm_112009.pdf [Internet]. [cité 27 avr 2020]. Disponible sur: https://www.has-sante.fr/upload/docs/application/pdf/2009-

11/premier_bilan_certif_vm_112009.pdf

31. 124000093.pdf [Internet]. [cité 1 mars 2020]. Disponible sur: https://www.viepublique.fr/sites/default/files/rapport/pdf/124000093.pdf

32. Bonnard $M$, Tétard J. Effet d'une formation en hypnothérapie sur le médecin généraliste et sur sa prise en charge des patients souffrant d'insomnie : enquête par entretiens individuels. Nice Sophia Antipolis; 2020.

33. Geoffrion J. Influence de l'hypnose éricksonienne sur la consommation en benzodiazépines et molécules apparentées chez des patients en Illeet- Vilaine et Côtes d'Armor. Thèse de médecine : Université de Rennes 1, "dactyl », 39. [Internet]. [cité 20 mars 2018]. Disponible sur: https://ecm.univ-rennes1.fr/nuxeo/site/esupversions/4fd239ea-8fdf-49fd-a3ee4d01981e7a21?inline

34. Roch CL. Le Roch C. Étude qualitative sur les impacts d'une formation à l'hypnose médicale pour des médecins généralistes d'île-de-France. Thèse de médecine : Université de Paris XI, 10 jan 2018, « dactyl », 100. 2018;82.

35. Cheveau C. Guérir d'un traumatisme psychique par hypnose. Paris: Josette Lyon; 2014.

36. Benhaiem J-M, Roustang F. L'Hypnose ou les portes de la guérison. Odile Jacob. Paris; 2012. 


\section{SERMENT D'HIPPOCRATE :}

« Au moment d'être admis(e) à exercer la médecine, je promets et je jure d'être fidèle aux lois de I'honneur et de la probité.

Mon premier souci sera de rétablir, de préserver ou de promouvoir la santé dans tous ses éléments, physiques et mentaux, individuels et sociaux.

Je respecterai toutes les personnes, leur autonomie et leur volonté, sans aucune discrimination selon leur état ou leurs convictions. J'interviendrai pour les protéger si elles sont affaiblies, vulnérables ou menacées dans leur intégrité ou leur dignité.

Même sous la contrainte, je ne ferai pas usage de mes connaissances contre les lois de l'humanité. J'informerai les patients des décisions envisagées, de leurs raisons et de leurs conséquences.

Je ne tromperai jamais leur confiance et n'exploiterai pas le pouvoir hérité des circonstances pour forcer les consciences.

Je donnerai mes soins à l'indigent et à quiconque me les demandera.

Je ne me laisserai pas influencer par la soif du gain ou la recherche de la gloire.

Admis(e) dans l'intimité des personnes, je tairai les secrets qui me seront confiés.

Reçu(e) à l'intérieur des maisons, je respecterai les secrets des foyers et ma conduite ne servira pas à corrompre les mœurs.

Je ferai tout pour soulager les souffrances.

Je ne prolongerai pas abusivement les agonies.

Je ne provoquerai jamais la mort délibérément.

Je préserverai l'indépendance nécessaire à l'accomplissement de ma mission.

Je n'entreprendrai rien qui dépasse mes compétences.

Je les entretiendrai et les perfectionnerai pour assurer au mieux les services qui me seront demandés. J'apporterai mon aide à mes confrères ainsi qu'à leurs familles dans l'adversité.

Que les hommes et mes confrères m'accordent leur estime si je suis fidèle à mes promesses ; que je sois déshonoré(e) et méprisé(e) si j’y manque. »

Serment D'Hippocrate.

https://www.conseil-national.medecin.fr/sites/default/files/medecins_ns_-_serment.pdf 


\begin{abstract}
:
Background:

In France, benzodiazepines are widely prescribed and $15 \%$ of their introduction will be extended beyond the time limit. The HAS (French National Authority for Health, Haute Autorite de Santé) recommends the use of non-medicinal alternatives. Hypnosis could be one of these alternatives.
\end{abstract}

\title{
Objective:
}

To evaluate the data of the Compensation on Public Health Objectives (ROSP in French) concerning prescriptions of benzodiazepines past the statutory deadline by the general practitioners (GP) trained in hypnotherapy.

\section{Methods:}

A cohort descriptive study was conducted from June to December 2019. The ROSP data for the prescriptions in 2019 of GP trained in hypnotherapy were collected. The two primary outcome measures were the rate of out of time limit prescriptions relative to the total number of hypnotic and anxiolytic benzodiazepines prescriptions (ROSP data).

\section{Results:}

189 GPs were contacted, representing $30 \%$ of the national population of GPs trained in hypnosis. Among the 189 GPs, only 81 were practicing in private practice with a convention. 24 could not be contacted and five refused to answer.

A total of 52 French private GP out of a sample of $81(64 \%)$ were interviewed by phone or email. The total number of patients surveyed was 52,000 .

$38.3 \%$ of hypnotic prescriptions and $14,8 \%$ of anxiolytic prescriptions were extended out of time limit for a national rate of respectively $42.8 \%$ and $14.8 \%$, with statistically no significant difference.

\section{Conclusions:}

The high participation rate and the sample size suggest that these results are representative. Training in hypnosis is not significantly correlated with better prescriptions of hypnotics or anxiolytics. A qualitative study is underway to better understand these results.

Keywords: General practice, Hypnosis, Hypnotic and Anxiolytic Benzodiazepines. 
UNIVERSITE NICE SOPHIA ANTIPOLIS

FACULTE DE MEDECINE 